\title{
Congenital crocodile tears: a key to the aetiology of Duane's syndrome
}

\author{
JAMES RAMSAY AND DAVID TAYLOR \\ From the Hospital for Sick Children, Great Ormond Street, London WCI
}

SUMMARY The occurrence from birth of copious lacrimation on eating in some patients with Duane's syndrome suggests that both are caused by dysgenesis or a lesion in the vicinity of the abducens nucleus in the pons.

The legend that crocodiles wept before devouring their victims gave birth to the term 'crocodile tears' (gustolacrimal reflex) which is now used for the condition of copious lacrimation associated with eating. Reports of acquired crocodile tears frequently appear, ${ }^{1}$ the symptom usually following traumatic or inflammatory conditions of the facial or greater superficial petrosal nerves. It is widely believed that the paroxysmal lacrimation results from the misdirection of regenerating parasympathetic secretomotor fibres subserving salivation. Reports of cases of congenital crocodile tears are rare. A summary of all reported cases (Table 1) shows that in all but the case of Antonelli, there is an associated abducens palsy or Duane's syndrome, and that in unilateral cases the lacrimal abnormality and eye movement disorder are ipsilateral, while in bilateral cases the movement disorder is also bilateral.

Duane's syndrome ${ }^{2}$ was originally described as a musculofascial anomaly, but more recent studies based on electromyography ${ }^{3-7}$ suggest that the main feature is co-contraction of the horizontal eye muscles, which distinguishes Duane's syndrome from an abducens palsy. Retraction is often inconspicuous, and Huber et al. ${ }^{6}$ pointed out that cocontraction may be revealed only by electromyography. It is possible that cases described as having an abducens palsy have in reality a Duane's syndrome. The diverse associated anomalies referred to in Table 1 follow closely the pattern of anomalies described in Duane's syndrome by Sachsenweger, ${ }^{8}$ Kirkham, ${ }^{9}$ and Pfaffenbach et al..$^{10}$ The occurrence of crocodile tears sheds some light on the causative lesion in Duane's syndrome.

\section{Case reports}

CASE 1

The child was a boy aged 3 years 4 months who

Correspondence to Dr D. Taylor. was the product of a normal pregnancy. Shortly after birth the parents had noted that there was no lacrimination from either eye when the child cried. From the time when solid foods were first taken, eating was accompanied by profuse lacrimation from both eyes. This had not been present on taking the bottle. No lacrimation occurred when soap or other irritants entered the eyes. From the age of 2 years there had been an increasing tendency for the eyes to move independently of one another on looking to the side. There was no relevant family history or past medical history. On examination, vision was 6/6 unaided in both eyes by the Sheridan Gardiner technique. There was a left, alternating convergent squint and a bilateral Duane's syndrome. Abduction was limited in each eye with retraction and upshoot of the adducting eye, and in addition adduction and convergence were slightly reduced. Investigation of the lacrimal defect confirmed abundant lacrimation on chewing a sweet. This was also present on chewing a tasteless rubber. Although corneal sensation was normal, no lacrimation was produced on stimulating the cornea with a cotton wool wisp or ammonia fumes.

General examination revealed a bland facial expression but normal emotional and voluntary facial movements. The distal plalanx of the little finger of each hand was markedly deviated towards the ring finger.

$X$-rays of skull and chest were normal. Eye movement recordings carried out by the Medical Research Council's Hearing and Balance Unit at the National Hospital, Queen Square, London, revealed that horizontal and vertical saccades could be generated in each eye in response to vestibular and optokinetic stimuli. Vestibulospinal reflexes were normal as judged by free-fall electromyography. ${ }^{11}$ Stapedial reflexes were normal, indicating a normal innervation of the stapedius muscle by the facial nerve. The 5-tone audiogram was normal. 
Table 1 Summary of all reported cases

\begin{tabular}{|c|c|c|c|c|c|}
\hline Case & $\begin{array}{l}\text { Crocodile } \\
\text { tearing }\end{array}$ & $\begin{array}{l}\text { Emotional } \\
\text { tearing }\end{array}$ & $\begin{array}{l}\text { Facial } \\
\text { weakness }\end{array}$ & $\begin{array}{l}\text { Duane's syndrome or } \\
\text { sixth nerve palsy }\end{array}$ & Other features \\
\hline Antonelli'is & Unilateral (R) & Absent & & & \\
\hline $\begin{array}{ll}\text { Lutman }^{36} & 1 \\
& 2 \\
& 3\end{array}$ & $\begin{array}{l}\text { Unilateral }(? \mathbf{R} / \mathbf{L}) \\
\text { Bilateral } \\
\text { Bilateral }\end{array}$ & $*$ & 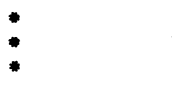 & $\begin{array}{l}\text { Unilateral (?R/L) } \\
\text { Bilateral palsy } \\
\text { Bilateral palsy }\end{array}$ & $\because$ \\
\hline Lillie $^{37}$ & ? Uni/bilateral & $\bullet$ & $\bullet$ & ? Uni/bilateral palsy & $\bullet$ \\
\hline $\begin{array}{ll}D^{\prime} E^{2} m o & 1 \\
2\end{array}$ & $\begin{array}{l}\text { Bilateral } \\
\text { Unilateral (R) }\end{array}$ & $\begin{array}{l}\text { Absent } \\
\text { Absent }\end{array}$ & $\begin{array}{l}\text { Absent } \\
\text { Absent }\end{array}$ & $\begin{array}{l}\text { Bilateral Duane's } \\
\text { Unilateral Duane's (R) }\end{array}$ & $\begin{array}{l}\text { Oxycephaly, facial asymmetry } \\
\text { hypochromia iridis, facial asymmetry }\end{array}$ \\
\hline Cricchi $^{39}$ & Bilateral & Absent & Absent & Bilateral Duane's & $\bullet$ \\
\hline Jampel, Titone ${ }^{40}$ & Unilateral (R) & Present & $\bullet$ & Unilateral palsy (R) & $\begin{array}{l}\text { Anisometropia, skull bossing, syndactyly } \\
\text { and arachnodactyly, scoliosis }\end{array}$ \\
\hline Sarda et al. ${ }^{41}$ & Unilateral (R) & $\bullet$ & Absent & Unilateral palsy (R) & $\bullet$ \\
\hline Regenbogen, Stein ${ }^{42}$ & Unilateral (L) & Present & Absent & Unilateral Duane's (R) & EMG features of Duane's syndrome \\
\hline $\begin{array}{ll}\text { Uemura, Tamura } & 1 \\
& 2 \\
3 \\
4\end{array}$ & $\begin{array}{l}\text { Bilateral } \\
\text { Bilateral } \\
\text { Bilateral } \\
\text { ? Uni/bilateral }\end{array}$ & $\begin{array}{l}\text { Absent } \\
\text { Minimal } \\
\text { Minimal }\end{array}$ & $\begin{array}{l}\text { Absent } \\
\text { Absent } \\
\text { Absent } \\
\text { Absent }\end{array}$ & $\begin{array}{l}\text { Bilateral Duane's } \\
\text { Bilateral Duane's } \\
\text { Bilateral Duane's } \\
\text { ? Uni/bilateral Duane's }\end{array}$ & $\begin{array}{l}\text { Bilateral deafness } \\
\text { EMG features of Duanes's syndrome } \\
\text { Supernumary auricle }\end{array}$ \\
\hline Brik, Athayde^t & Bilateral & $*$ & Absent & Bilateral Duane's & Klippel-Feil anomaly \\
\hline Trieschmann $^{28} \begin{array}{l}1 \\
2\end{array}$ & $\begin{array}{l}\text { Bilateral } \\
\text { Bilateral }(\mathbf{R}>\mathbf{L})\end{array}$ & $\begin{array}{l}\text { Absent } \\
\text { Present }\end{array}$ & $\begin{array}{l}\text { Bilateral } \\
\text { Unilateral (R) }\end{array}$ & $\begin{array}{l}\text { Bilateral Duane's } \\
\text { Bilateral Duane's }(\mathbf{R}>\mathbf{L})\end{array}$ & $\begin{array}{l}\text { Bilateral deafness, deformity of auricles } \\
\text { Deformity of auricles }\end{array}$ \\
\hline Ramsay, Taylor $\begin{array}{l}1 \\
2\end{array}$ & $\begin{array}{l}\text { Bilateral } \\
\text { Bilateral }\end{array}$ & $\begin{array}{l}\text { Absent } \\
\text { Absent }\end{array}$ & $\begin{array}{l}\text { Moebius } \\
\text { Moebius }\end{array}$ & $\begin{array}{l}\text { Bilateral Duane's } \\
\text { Bilateral Duane's }\end{array}$ & $\begin{array}{l}\text { Deformity of fingers } \\
\text { Bilateral deafness, deformity of auricle }\end{array}$ \\
\hline
\end{tabular}

-Indicates that the presence or absence of the feature was not recorded.

CASE 2

The child, a boy aged 3 years 8 months when first seen, was the product of a full-term normal pregnancy. The parents had noted that from birth copious lacrimation occurred from both eyes on breast feeding. It continued after the child started taking solid foods. When eating dry foods he drank repeatedly. There had been no lacrimation from either eye when crying, and the parents were unaware of any eye movement disorder. He had been deaf from birth. There was no relevant family history or past medical history. On examination the vision was 3/6 in each eye by the Ffooks symbols. There was a small left, alternating convergent squint and a bilateral Duane's syndrome with marked limitation of abduction and slight retraction on attempted adduction in each eye. Adduction and convergence were reduced. Investigation of the lacrimal defect showed lacrimation on chewing a sweet or a tasteless rubber. Corneal sensation was normal, but no lacrimation was produced on stimulation of the cornea with a cotton-wool wisp or ammonia fumes.

General examination revealed a bland facial expression but normal emotional facial movements. Examination of the ears revealed a rudimentary right auricle and atresia of the right external audi- tory meatus. The tympanic membrane could not be seen. The left auricle and external auditory meatus and drum appeared normal. There was response only to the loudest auditory stimuli, and it was felt that even this slight response might be to noiseinduced vibration of the skull. There was a marked bilateral pes planus.

$X$-rays of skull, spine, and chest appeared normal. Eye movement recordings revealed a complete inability to generate horizontal saccades in either eye in response to vestibular or optokinetic stimuli. Small visually evoked vertical saccades could be generated but there was no vertical doll's head response. Vestibulospinal reflexes were absent on free-fall electromyography.

In these cases the features of bilateral abduction weakness and bland facial expression are suggestive of the Moebius syndrome. In case 2 the additional feature of a marked disturbance of vestibular mediated reflexes may be suggestive of a widespread lower brain stem disturbance.

\section{Discussion}

Two main theories have been advanced to account for the electromyographic feature of Duane's syndrome. One theory supported by Blodi et al. ${ }^{5}$ 
and Sato ${ }^{3}$ suggests that the defect lies at a supranuclear level, while the other supported by Hoyt and Nachtigäller ${ }^{12}$ and Huber $^{13}$ proposes that the defect is peripheral, there being a developmentally defective innervation of the lateral rectus by the abducens nerve with a variable pattern of innervation of the other ocular muscles.

The existence of a supranuclear pontine centre for lateral gaze was postulated by Crosby. ${ }^{14}$ Carpenter et $a .^{15}$ suggested that in monkeys this centre is near or within the abducens nucleus. They showed that unilateral stereotactic destruction of the abducens nucleus was followed by gaze deviation to the opposite side. In the tissue studies of the same animals the preterminal degeneration was most marked in the contralateral medial longitudinal fasciculus and distributed preferentially to the ventral nucleus of the contralateral oculomotor nuclear complex (cells whose axons innervate the contralateral medial rectus). Similarly, Graybiel and Hartweig ${ }^{16}$ showed that ${ }^{3} \mathrm{H}$ proline injected into the abducens nucleus of cats appeared within the contralateral ventral nucleus of the oculomotor nuclear complex. They proposed that these interneurons are the cells essential in conjugate lateral gaze. A theory that seeks to explain Duane's syndrome on the basis of a supranuclear lesion must therefore account for the normal action of the contralateral medial rectus.

The innervational theory suggested by Huber et $a .^{6}$ and expanded by Hoyt and Nachtigäller ${ }^{12}$ proposed that a maldevelopment of the abducens nucleus occurs, resulting in innervation of the lateral rectus by fibres of the oculomotor nerve, the variable electromyographic features reflecting the innervation of the lateral rectus by different branches of the oculomotor nerve. Unfortunately the anatomical evidence for substitute innervation is inconclusive, since no case of Duane's syndrome has been examined at necropsy with both histological examination of the brain stem and dissection of the nerves as far as the eye muscles.

The post-mortem study of a case of Duane's syndrome by Matteuci ${ }^{17}$ showed aplasia of the abducens nucleus. A case of bilateral abducens nerve palsy ${ }^{18}$ showed the absence of both abducens nerves with diminutive nuclei. Some anatomical support for substitute innervation has been drawn ${ }^{12}$ from cadaver dissections (cases without information regarding eye movements in life) in which absence of the abducens nerve was associated with innervation of the lateral rectus by the oculomotor nerve. ${ }^{19-22}$

However, these findings must be interpreted with caution. Svitzer ${ }^{23}$ in cadaver dissections and Kimmel $^{24}$ in histological studies of embryo rabbits have shown that 'anastomosis' between the oculomotor nerve and the abducens nerve sometimes occurs within the cavernous sinus and orbit. Absence of the abducens nerve in cadaver dissections must also be interpreted with caution. Kimmel ${ }^{24}$ and Bremer ${ }^{25} 26$ showed that in some cases the fibres from the abducens nucleus do not emerge from the brains stem at the classical site. The innervation of the lateral rectus by a branch of the oculomotor nerve in the cadaver dissections of Generali, ${ }^{19}$ Tillack and Winer, ${ }^{20}$ Munnicks, ${ }^{21}$ and Fasebeck ${ }^{22}$ may reflect only an abnormal route by which abducens motoneurons reach their destination. In Tillack and Winer's case the abducens nucleus was reported as normal, which might be taken to suggest that although the 'abducens nerve' could not be found the motoneurons must have existed.

Bremer ${ }^{26}$ suggested that absence of the abducens nerve might arise through a delay in the development of the ocular musculature, allowing the fibres of the abducens nerve to pass caudally, attracted by the postotic musculature. These fibres would disappear with the involution of the postotic mesoderm. Pfaffenbach et al. ${ }^{10}$ suggested that a teratogenic stimulus at an early stage of embryogenesis caused Duane's syndrome and its associated anomalies. Of 55 children with thalidomide embryopathy studied by Papst, ${ }^{27} 4$ had Duane's syndrome, and of those with eye movement disturbances many had facial pareses and ear deformities. He suggested that these disorders occurred between 34 and 39 days after the mother's last menstrual period. The other abnormalities associated with these cases of Duane's syndrome are comparable to those described by Pfaffenbach et al. ${ }^{10}$ Trieschmann ${ }^{28}$ reported 3 patients with thalidomide embryopathy who showed crocodile tears, abducens nerve palsy, or Duane's syndrome and facial paresis, and 2 showed deformities of the pinnae of the ears.

If Duane's syndrome is of teratogenic origin the presence of crocodile tears in some cases sheds light on the site of the lesion. The close association of the eye movement disorder with the lacrimal disorder, respecting laterality in the unilateral cases and being bilateral in bilateral cases, suggests that a single teratogenic lesion is responsible for both. While the site of the lacrimal centre within the brain stem is uncertain, the similar embryological origin of lacrimal and salivary glands suggests that the centres controlling both lie in the same area. A centre controlling salivation exists in the lower brain stem, but its exact location is uncertain.

Kohnstamm ${ }^{29}$ and Yagita and Hayama, ${ }^{30}$ using the technique of retrograde degeneration, suggested a centre in the lateral reticular formation at the level of the facial nucleus. Using stereotactic 
stimulation Magoun and Beaton ${ }^{31}$ in monkeys and Chatfield ${ }^{32}$ and Wang ${ }^{33}$ in cats identified 2 areas in the lower brain stem that yield largely ipsilateral salivary secretion. They confirmed that salivation followed stimulation in the lateral area demonstrated by Kohstamm ${ }^{29}$ and Yagita and Hayama, ${ }^{30}$ but in addition a similar response was obtained from the dorsal paramedian reticular formation. Stimulating the intervening area of the reticular formation gave a limited response. Different interpretations were put on these findings. Chatfield and Wang thought that the salivary centre lay ventrolaterally near the facial nucleus and that secretion following stimulation in the dorsomedially placed area represented the stimulation of efferent fibres lying within the genu of the root of the facial nerve. Magoun and Beaton, ${ }^{31}$ however, felt that secretion produced by stimulation more laterally in the brain stem reflected the passage of efferent fibres from dorsomedial cells.

In the embryo rabbit Kimmel ${ }^{2434}$ found a genu only in fibres from cells of the special visceral efferent column that contribute to the motor root of the facial nerve. This suggests that it is incorrect to ascribe secretion from stimulation in the dorsomedial area to stimulation of efferent neurones, and thus the interpretation of Magoun and Beaton ${ }^{31}$ seems more plausible, that is, that the salivary centre lies dorsomedially with efferents passing laterally through the reticular formation. A dorsomedial centre mediating parasympathetic function would not be surprising in view of the position of the Edinger-Westphal nucleus and the dorsal motor nucleus of the vagus. The cells lying rostrally in this dorsomedial column (that is, in closest association with the abducens nucleus) would subserve lacrimal secretion (indeed in the series of Magoun and Beaton 1 animal showed ipsilateral lacrimation on stimulation in this area).

The most logical explanation of the lacrimal and eye movement disorders in Duane's syndrome would be a lesion causing a nuclear degeneration or dysgenesis in the immediate vicinity of the abducens nucleus, the paradoxical aspects of Duane's syndrome and the lacrimal disorder being the result of a substitute innervation of the lateral rectus by fibres from the oculomotor nerve and the lacrimal gland by fibres subserving salivation.

The authors thank Dr Michael Gresty and Dr Michael Halmagyi for carrying out the eye movement recordings on both patients.

\section{References}

${ }^{1}$ Chorobski J. Syndrome of crocodile tears. Arch Neurol Psychiat 1951; 65: 299-318.

${ }^{2}$ Duane A. Congenital deficiency of abduction associated with impairment of adduction, retraction movements, contraction of the palpebral fissure and oblique movements of the eye. Arch Ophthalmol 1905; 34: 133.

${ }^{3}$ Sato $\mathrm{S}$. Electromyographic study on retraction syndrome. Jpn J Ophthalmol 1960; 4: 57-66.

${ }^{4}$ Papst W, Esslen E. Sur Åtiologie der angeborenen Abduzenslähmung. Klin Monatsbl Augenheilkd 1960; 137: 306-27.

${ }^{5}$ Blodi FC, Van Allen MW, Yarbrough JC. Duane's syndrome, a brainstem lesion. Arch Ophthalmol NS 1964; 72: $171-7$.

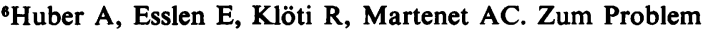
des Duane-Syndroms. Albrecht von Graefes Arch Klin Ophthalmol 1964; 167: 169-91.

7Scott AB, Wong GY. Duane's syndrome. Arch Ophthalmol 1972; 87: 140-7.

${ }^{8}$ Sachsenweger R. Augenmuskellähmungen; ein Handbuch für ophthalmologen Neurologen und Internisten. Leipzig: Thieme, 1966.

${ }^{9} \mathrm{Kirkham}$ TH. Inheritance of Duane's syndrome. $\mathrm{Br} J$ Ophthalmol 1970; 54: 323-9.

${ }^{10}$ Pfaffenbach DD, Cross HE, Kearns TP. Congenital anomalies in Duane's retraction syndrome. Arch Ophthalmol 1972; 88: 635-9.

${ }^{11}$ Greenwood R, Hopkins A. Landing from an unexpected fall and a voluntary slip. Brain Res 1976; 99: 375-86.

${ }^{12}$ Hoyt WF, Nachtigäller $H$. Anomalies of ocular motor nerves. Am J Ophthalmol 1965; 60: 443-8.

${ }^{13}$ Huber A. Electrophysiology of the retraction syndromes. Br J Ophthalmol 1974; 58: 293-300.

${ }^{14}$ Crosby EC. Relation of brain stem centres to normal and abnormal eye movements in the horizontal plane. J Comp Neurol 1953; 99: 437-79.

${ }^{15}$ Carpenter MB, McMasters RE, Hanna GR. Disturbances of Conjugate horizontal eye movements in the monkey. Arch Neurol 1963; 8: 231-47.

${ }^{16}$ Graybiel AM, Hartwieg EA. Some afferent connections of the oculomotor complex in the cat: an experimental study with tracer techniques. Brain Res 1974; 81: 543-51.

${ }^{17}$ Matteucci P. I difetti congeniti di abduzione ('congenital abduction deficiency') con particolare riguardo alla patogenesi. Rassegna Italiana d'Ottalmologia 1946; 15: 345-80.

${ }^{18}$ Phillips WH, Dirion JK, Graves GO. Congenital bilateral palsy of the abducens. Arch Ophthalmol 1932; 8: 355-64.

${ }^{19}$ Generali G. Considerazioni anatomiche, fisiologiche e patologiche intorno il nervo gran simpatico. Ann Universali Med Compilati del Dottore A Omode 1842; 104: 60.

${ }^{20}$ Tillack TW, Winer JA. Anomaly of the abducens nerve. Yale J Biol Med 1962; 34: 620-4.

${ }^{21}$ Munniks. Quoted in Henle J. Handbuch der Systematischen Anatomie des Menschen. Veiweg, 1879.

${ }^{22}$ Fasebeck. Quoted in Henle J. Handbuch der Systematischen Anatomie des Menschen. Vieweg, 1879.

${ }^{23}$ Svitzer. Quoted in Henle J. Handbuch der Systematischen Anatomie des Menschen. Veiweg, 1879.

${ }^{24} \mathrm{Kimmel} \mathrm{DL}$. Differentiation of the bulbar motor nuclei and the coincident development of associated root fibres in the rabbit. J Comp Neurol 1940; 72: 83-148.

${ }^{25}$ Bremer JL. Aberrent roots and branches of the abducent and hypoglossal nerves. J Comp Neurol Psychol 1908; 18: 619-39.

${ }^{26}$ Bremer JL. Recurrent branches of the abducens nerve in human embryos. Am J Anatomy 1921; 28: 371-98.

${ }^{27}$ Papst W. Thalidomid und kongenitale Anomalien der Augen. Dtsch Ophthalmol Ges 1963; 65: 209-15.

${ }^{28}$ Trieschmann W. Krokodilstränen bei Conterganschäden. Klin Monatsbl Augenheilk 1973; 162: 546-50.

${ }^{29}$ Kohnstamm O. Der Nucleus salivatorius Chordae tympani (nervi intermedii) Anat Anz 1902; 21 : 362-3.

${ }^{30}$ Yagita K, Hayama S. Uber das Speichelsekretionscentrum. 
Neurologisches Zentralblatt 1909; 28: 738-53.

${ }^{31}$ Magoun HW, Beaton LE. The salivatory motor nuclei in the monkey. Am J Physiol 1942; 136: 720-5.

${ }^{32}$ Chatfield PO. Salivation in response to localised stimulation of the medulla. Am J Physiol 1941; 133: 637-41.

${ }^{33}$ Wang SC. Localization of the salivatory center in the medulla of the cat. $J$ Neurophysiol 1943; 6: 195-202.

${ }^{34} \mathrm{Kimmel}$ DL. Development of the afferent components of the facial glossopharyngeal and vagus nerves in the rabbit embryo. J Comp Neurol 1942; 74: 447-65.

${ }^{35}$ Antonelli A. Anomalie fonctionnelle congénitale de la glande lacrymale du coté droit. Clinique Ophthalmologique 1902; 8: 35-6.

'Lutman FC. Paroxysmal lacrimation when eating. Am J Ophthalmol 1947; 30: 1583-5.

${ }^{37}$ Lillie WI. Quoted in Lutman FC. Paroxysmal lacrimation when eating. Am J Ophthalmol 1947; 30: 1583-5.

"D'Ermo F. Su due casi di sindrome delle lacrime di cocco- drillo di natura congenita, associata a sindrome di Türk. Boll Oculist 1949; 28: 273-88.

${ }^{39} \mathrm{Cricchi}$ M. Su di un nuovo caso di sindrome di lacrime di coccodrillo di natura congenita associata alla sindrome di Stilling-Türk-Duane. Boll Oculist 1962; 41: 587-94.

${ }^{40}$ Jampel RS, Titone C. Congenital paradoxical gustatorylacrimal reflex and lateral rectus paralysis. Arch Ophthalmol 1962; 67: 123-6.

"Sarda RP, Charan H, Nagpal PN. Congenital neurolacrimal syndrome. Ophthalmologica 1967; 153: 174-8.

${ }^{42}$ Regenbogen L, Stein R. Crocodile tears associated with homolateral Duane's syndrome. Ophthalmologica 1968; 156: 353-60.

${ }^{43}$ Uemura $Y$, Tamura $H$. Congenital gustato-lacrimal syndrome. Jpn J Clin Ophthalmol 1968; 22: 489-95.

"Brik M, Athayde A. Bilateral Duane's syndrome, paroxysmal lacrimation and Klippel-Feil anomaly. Ophthalmologica 1973; 167: 1-8. 